\title{
234-4 - ABELLAITE, A SUPERGENE CARBON-BEARING MINERAL FOUND IN AN ABANDONED URANIUM MINE IN THE SOUTHERN PYRENEES (NE IBERIAN PENINSULA)
}

$\leftrightarrow \leftarrow^{\uparrow}$

Wednesday, 25 September 2019

8:45 AM - 9:00 AM

Phoenix Convention Center - Room 125AB, North Building

\begin{abstract}
Abellaite (IMA 2014-111) is one of the minerals predicted to exist by Hazen et al. (2016) in their seminal paper on carbon mineral ecology. It is a supergene mineral that was found in the galleries of the long-disused Eureka mine (Southern Pyrenees, Catalonia, Spain). The mineral was named after the amateur mineralogist Joan Abella i Creus (b. 1968), who thoroughly explored the deposits of the mine and first collected the mineral.
\end{abstract}

In this contribution we present an overview about the discovery and characterization of abellaite, ideally $\mathrm{NaPb}_{2}(\mathrm{CO} 3)_{2}(\mathrm{OH})$, with special emphasis on the solution and refinement of its crystal structure (sg. $\mathrm{P} 6_{3} \mathrm{mc}$ ). We also discuss the exceptional Cu-U-V mineralizations of the Eureka mine, which are located in reduced lower Triassic (Buntsandstein) sandstones. The site includes up to four different stages of mineralization. Abellaite, like other associated supergene minerals such as andersonite or cejkaite, is a post-mine neoformation mineral deposited on the walls of the galleries.

We also present a few historical notes about the Eureka mine, and in particular about the plans of Franco's dictatorship in the 50s and 60s of the last century to extract uranium minerals and enter the nuclear era. Finally, we discuss recent geological/cultural heritage issues related to the site, which has been badly damaged by mineral vendors. The spoliation of the mine has interfered ongoing studies of possible new minerals, like a NaFe-V compound associated to abellaite, the characterization of which has no longer been possible due to the dehydration of the available samples.

Geological Society of America Abstracts with Programs.

Vol. 51, No. 5, ISSN 0016-7592 doi: 10.1130/abs/2019AM-335970

(c) Copyright 2019 The Geological Society of America (GSA), all rights reserved.

\section{Authors}

Jordi Ibanez-Insa

Spanish Council of Scientific Research (CSIC)

Xavier Llovet

University of Barcelona

Núria Oriols 